DOI: https://doi.org/10.24144/2409-6857.2020.2(56).89-97

УДК 339.923:061.1СС+339.97:616-036.21

Черленяк I.I., Курей О.А., Федурця В.П.

\title{
ОСОБЛИВОСТІ ФОРМУВАННЯ УПРАВЛІНСЬКИХ ТА ЕКОНОМІЧНИХ РІШЕНЬ СТРУКТУРАМИ ТА ІНСТИТУТАМИ ЕС НА ПЕРШИХ ЕТАПАХ КРИЗИ «СОVID-19»
}

\begin{abstract}
Стаття є актуальним дослідженням рівня рефлективності, реактивності (своєчасності) та результативності управлінських рішень державної та самоврядних влад країн Свропейського Союзу на виклики стартового етапу кризи, викликаної тригером коронавірусу. У роботі проведене оцінювання змісту інструментів антикризової політики, стратегій подолання кризи в краӥнах-членах та в СС як у цілісній організаційній системі. Здійснений аналіз доцільності запозичення певних рімень та прийомів із застосованого в країнах ЄС управлінського інструментарію; виявлення та прогнозування підходів, придатних для використання в умовах сучасної кризи в Україні, яка декларує в якості цілей розвитку економічне та політичне асоціювання з $Є С$.
\end{abstract}

Ключові слова: криза, управління, Європейський Союз, пандемія, COVID-19, інститут, компетенція, інструмент, координація.

Постановка проблеми. Донедавна слово «вірус» у більшості громадян різних держав асоціювалося виключно 3 неприємними симптомами та ймовірністю захворіти, в середовищі програмістів і технологів - зі збоями в роботі програмного забезпечення та інформаційних систем загалом. В приватних корпораціях та державних управлінських середовищах, охоплених сучасними системами інформаційної підтримки автоматизованих систем регулювання чи то технологічних комплексів, чи то фінансово-банківських комплексів, чи комплексів баз даних державної безпеки, вірус асоціювався із загрозами для управління та економіки (згадаймо вірус РЕТYА). Здавалося, що глобальна система науки медицини - економіки - охорони здоров'я у XXI ст. настільки технологічна та потужна, що найбільшою загрозою $є$ віруси в інформаційних мережах технологічного забезпечення. Сучасний світ у 2020 році (через 1480 років після першої за

(C) Черленяк I.I., доктор наук 3 державного управління, проф., професор кафедри бізнесадміністрування, маркетингу та менеджменту, ДВНЗ «Ужгородський національний університет», тел.+380668201416, E-mail: ivan.cherlenjak@uzhnu.edu.ua

Курей О.А., к.е.н., доц., доцент кафедри бізнесадміністрування, маркетингу та менеджменту, ДВНЗ «Ужгородський національний університет», тел.+380502171408, E-mail: oksana.kurei@uzhnu.edu.ua

Федурця В.П., к.е.н., доц., доцент кафедри бізнес-адміністрування, менеджменту, ДВНЗ «Ужгородський національний університет», тел.+380509715999, E-mail: vasyl.fedurtsia@uzhnu.edu.ua ліком пандемії чуми, яка почалася у 541 році в Східній Римській Імперії за правління Юстиніана) заново дуже гостро почав поволі розуміти, що не тільки комп'ютерний вірус, але і «звичайний» біологічний вірус здатен запускати незворотні кризові процеси не тільки в біологічних і системах штучного інтелекту, а й у системах соціальних та економічних. Глобалізований технологіями комунікацій світ почав усвідомлювати реальні загрози, коли міграція областей циркуляції вірусу швидко створила якісно нове сплітання кризових факторів в економіці, медицині, організації соціального життя тощо. Це створило явні загрози не тільки процесам глобалізації, але i нормальному функціонуванню національних економік.

3 іншого боку, перед дослідниками відкрилася унікальна можливість в реальному часі спостерігати за реакцією різних моделей організації соціально-економічних систем на комплексний політико-економічний шок, заподіяний поширенням у сучасному соціальноекономічному середовищі вірусу біологічного походження. Незвичним стало те, що одночасно в різних галузях та різних територіальних одиницях, економічні кризи почали провокуватися не шоками споживання або шоками пропозиції, а безпосередньо шоками етапів динаміки пандемії. Всі економічні процеси критично трансформувалися. У цьому фокусі нового змісту актуальності набула суперечка про те, яка модель взаємодії ринку й держави здатна протистояти наслідкам впливу пандемії на суспільство загалом та економіку зокрема, а точніше: яка модель ринку здатна реагувати на шоки пандемії більш ефективно - модель 
ліберального ринку чи модель координованого ринку?

Для першої характерна максимальна свобода ринкового механізму в алокації ресурсів та встановленні рівнів заробітної плати (американська традиція). Модель координованого ринку (притаманна переважній більшості країн ЄC), натомість, має численні надбудови, покликані вчиняти соціально значимий регулюючий вплив на економіку, а тому є більш повільною в адаптації до змін [1]. Проте, координовані економіки, як виявилося, дещо краще вирішують проблеми, що вимагають злагодженої реакції всього суспільства, як от покращення сфери охорони здоров'я, державна допомога бізнесу тощо.

Для країн ЄС своєрідними координаторами дій у процесі адаптації до шоків COVID-19 крім національних урядів стали також наднаціональні структури-інститути

Співтовариства.

Особливості формування управлінських та економічних рішень становлять аспекти предмету дослідження цієї статті. Представляє і науковий, i практичний інтерес: дослідження доцільності запозичення певних рішень та прийомів із застосованого в країнах $Є C$ управлінського інструментарію; виявлення та прогнозування, що саме 3 попереднього досвіду генерування управлінських рішень у масштабі такої мегавимірної організаційної системи, як $€ \mathrm{C}$, придатне для застосування в умовах сучасної кризи в Україні, яка декларує в якості цілей розвитку економічне та політичне асоціювання з СС.

Аналіз останніх досліджень і публікацій. Дане дослідження $є$ логічним продовження нашої попередньої роботи [2], покликаної проаналізувати фактори розгортання економічної компоненти глобальної кризи 2020 р., порівняти джерела, механізми і наслідки кризи 2008-2010 pp. та кризи 2020 р. і з'ясувати роль фінансових інструментів у процесі оцінки цінностей та вартостей системи антикризового управління. Оскільки проблематика дослідження є відносно новою і маловивченою, для формулюванні своїх цілей, результатів і висновків ми спиралися в основному на фактологічні, статистичні та нормативні матеріали. Теоретичну основу аналізу склали роботи: П.Хол та Д.Соскіс [1] стосовно ролі інституцій і фірм в національних економіках, визначення й розмежування понять ліберальної та координованої моделей ринку; А.Бойн [3] в частині формулювання рис та особливостей транскордонних криз; М.Екенгрен та М.Грінлер [4], що аналізують кризовий менеджмент СС, здійснивши спробу визначити характеристики європейської кризи; угорського дослідника
Н.Сіярто [5] стосовно кроків Свропейської комісії в умовах розгортання пандемії та посилення іiі впливу на економіку ЄC.

Формулювання цілей статті. Метою статті є: аналіз рівня рефлективності, реактивності (своєчасності) та результативності управлінських рішень державної та самоврядних влад країн $Є С$ на виклики стартового етапу кризи, викликаної тригером коронавірусу; оцінювання змісту інструментів антикризової політики, стратегій подолання кризи в країнах-членах та в СС як цілісній організаційній системі.

Опис основного матеріалу дослідження. Організаційна система $€ \mathrm{C} \epsilon$ складноструктурованою трилистою функціонально-просторовою композицією гармонізованих інтересів-мотивацій ресурсів певної групи автономних акторів політикоекономічної дії. Агрегація систем «ресурсимотивації-компетенції-інтереси» автономних акторів призводить до формування нового рівня якості економічної ринкової інформації в просторі розвитку продуктивних сил національних економік країн учасників. Але гармонізація тріади «мотивація-інтересиможливості» відбувається лише при досягненні певної мінімальної та оптимальної комунікаційної щільності. Підтримання такого оптимального рівня комунікаційної спільності забезпечуються специфічними загальними управлінськими структурами, тобто інститутами Європейського Союзу: Європейською радою, Європейським парламентом, Радою $\mathrm{CC}$, Європейською комісією, Рахунковою палатою та Європейським центральним банком. Ці інститути здійснюють загальне рамкове управління на просторі відповідальності Європейського Союзу шляхом застосування інструментів «вторинного законодавства».

Правовий конструкт «вторинне законодавство» не визначений установчими документами ЄC. Він, скоріше, $є$ нарощуваним продуктом прецедентного міжнародного права та логічного документального оформлення аналітично-управлінської діяльності згаданих інституцій ЄС. Поняття «вторинне законодавство» використовують у наукових працях, документах i матеріалах Європейської комісії та інших інститутів Європейського Союзу. До вторинного законодавства ЄС відносять правові акти, прийняті інститутами Свропейського Союзу, що мають відповідну юридичну форму регламенту, директиви, рішення, рекомендації, висновку (ст. 288 Договору про функціонування (С). Вторинне законодавство інколи визначають як похідне. 
Його норми розробляються на основі первинного законодавства, однак, створюються вони та приймаються виключно інститутами $\mathrm{EC}$ iз застосуванням законодавчих процедур [6].

Незважаючи на високу координаційну роль інституцій $€ \mathrm{C}$, усе ж основними політичними та управлінськими акторами Європейського Союзу, як продемонстрував BREXIT, і далі залишається влада національних держав країн-членів. Проте, в нормальних (не кризових) умовах важливими «автоматичними» факторами спільності $\epsilon$ так званий «європейський дух» та «загальний європейський менталітет». Стосовно таких «соціокапітальних» факторів спільності, варто відзначити, що аналіз можливих ролей $Є С$ у врегулюванні криз повинен розпочинатися із пошуку відповідей на два запитання: 1) які кризи насправді можна вважати «європейськими»? та 2) яким потенціалом володіє ЄС для управління такими кризами?

Один із варіантів відповіді на перше питання ті кризи, які загрожують європейським цінностям. Останні, у свою чергу, гарантують громадянам ЄС добробут, вільну торгівлю, захист основних прав людини, безпеку, як особисту, так i, наприклад, безпеку харчових продуктів тощо. Процес управління такими кризами повинен базуватися саме на захисті громадян $Є \mathrm{C}$ від негативних наслідків криз, що загрожують існуванню та розвитку європейських цінностей [4]. Але, разом із тим, необхідно зважати на створювані управлінськими рішенням інститутів та країн членів СС виклики та ризики для норм i можливостей забезпечення прав і свобод особи та громадянина, зокрема, економічної свободи і права на підприємницьку діяльність.

Необхідно також зважати на те, що європейська криза - це ще й криза транскордонна. Подібні кризи здатні за визначенням швидко долати географічні, культурні, юридично визначені кордони національних держав i ïx угрупувань. Тому підходи до класифікації, визначення змісту та шляхів управління такими кризами значно ускладнюються для систем менеджменту різного рівня. Крім цього, криза за своєю природою $\epsilon$ складною системою взаємопов'язаних ефектів впливу на різні сфери життєдіяльності суспільства, тому й управління кризами $\epsilon$ комплексним механізмом рішень суб'єктів управління. У зв'язку з цим, в теорії антикризового управління пропонуються два підходи до розв'язання транскордонних криз: спрощувати системи та ізолювати їх окремі елементи (так званий «рух назад: будівництво стін») або створювати альтернативні чи компліментарні стратегії реагування на кризові явища, формування здатності поглинання суспільством їх наслідків (так званий «рух вперед: підготовка ефективних відповідей») [3].

Що стосується питання про загальний потенціал СС управляти кризовими ситуаціями, то однією з проблем пошуку відповіді на нього $€$ дослідження системи розподілу повноважень на різних рівнях управління СС та спектру зв'язків цієї системи 3 національними моделями прийняття рішень у кризових ситуаціях країнамичленами СС. Союз не може змусити національні органи здійснювати загальноєвропейські заходи, якщо національні органи не делегували це повноваження ЄС. Тим не менше, навіть за відсутності «загальної» державної політики та формальної ієрархії влади, стверджується, що, зокрема щодо питань, які становлять міжнародний інтерес, серед країн-членів $Є С$ склався «координаційний рефлекс»: вони, як правило, координують свої дії на рівні ЄС, в тому числі й у сфері антикризового управління. Якщо держави-члени рухатимуться в одному напрямку протягом більш тривалого періоду часу, координуючи свої національні цивільні та військові структури управління й захисту, вони можуть виробити спільний погляд на кризи, загрози та питання безпеки [4]. Таким чином, згадана нами раніше тріада «мотивація-інтересиможливості» має всі шанси 3 хиткої єдності динамічних агрегатів, яку тримають у певному спільному руслі розвитку насамперед прецеденти попередніх успішних рішень на спільну користь, перетворитись на більш стабільну й однорідну конструкцію реагування на виклики кризи. Але цей процес потребує постійної підтримки та уваги експертів, громад та громадськості.

Короновірусна криза сьогодні вражає всі складові трилистого простору $\mathrm{EC}$, що, безперечно, впливає на ефективність упровадження управлінських рішень не тільки членами $\mathrm{EC}$, а також країнами, що мають довгострокові асоціативні зв'язки з СС. У цьому ключі зауважимо, що на здатність ЄС досить швидко виробляти раціональні управлінські рішення в умовах початкової фази короновірусної кризи позитивно вплинула «залишкова організаційна пам'ять» боротьби зі кризою 20082010 pp. Саме у той час була апробована певна система управлінських рішень, поступово успішно гармонізована як по часовим параметрам, так i по рівням інтегральної відповідальності урядів країн-членів, так i компетентних органів СС загалом. У той час початковими були фінансові та економічні процеси, спровоковані як зовнішнім «втручанням», так і швидко сформованою дуже 
зримою кризою суверенних боргів, що набула максимуму в період 2010-2012 рр. Логіка прийняття управлінських рішень тоді була така: спочатку на рівні урядів країн-членів були прийняті антикризові заходи щодо тих проблем порушення координації та взаємодії між ринковими економіками країн-членів, які потенційно могли розірвати необхідний рівень економічної інтеграції СС як спільного ринку. Після цього почалося активна розробка низки управлінських рішень щодо цілісного регулювання збоїв у процесах ринкової координації економічних агентів $\mathrm{CC}, 3$ одного боку, та пошуки алгоритмів рішень для організації ефективної допомоги країнам Єврозони, що найбільше потерпали від кризи в силу своєї відносної бідності, з іншого. Для цього незабаром приступили до створення нових інститутів і регламентів економічної поведінки під егідою органів економічного керівництва СС.

Багато експертів вважали, що такий підхід $є$ не стільки демонстрацією здатності усвідомленого управління антикризовими заходами та процесами, спрямованого на досягнення обгрунтованої системи цілей i збалансованих результатів, як, швидше, комплексом спроб застосувати вже апробовані раніше прийоми. Тим не менш, тоді ці першочергові управлінські рішення першими дали короткострокові сприятливі результати: вони зупинили поглиблення кризи суверенних боргів та протистояли розпаду Єврозони. А починаючи 3 2012 року уповноваженим органам ЄС вдалося виробити середньострокову й довгострокову послідовність програм для управління подальшим економічним розвитком структур СС. Саме на цьому етапі були створені дієві інструменти управління факторами, що генерують або активують кризові феномени $\mathrm{i}$ процеси.

Компаративістський аналіз підходів та інструментів і на рівні країн-членів, і на рівні інститутів важливий тому, що в умовах сучасної кризи, на відміну від кризової ситуації 2008 року, коли першочергові управлінські рішення в ЄС були прийняті саме на рівні урядів країн-членів, ситуація із пріоритетністю джерел генерування рішень більш заплутана. 3 одного боку, це зрозуміло, оскільки через більшу монолітність системи державного управління й директивної обов'язковості на рівні окремих країн, рішення галузевого антикризового характеру для локальних територій, окремих регіонів країнчленів можна оперативніше розробити й реалізувати на рівні структур національних урядів і парламентів. Компаративістський аналіз указує, зокрема, що через кілька тижнів від початку санітарної та медичної компонент кризи, яка в СС в лютому 2020 р. (рис.1) зримо стартувала на півночі Італії, «залишкова антикризова організаційна пам'ять» структур та інститутів СС спрацювала ще раз: усі національні уряди та органи місцевого самоврядування $Є С$ уже в лютому зрозуміли, що згодом вони також зустрінуться 3 аналогічними або спільними кризовими загрозами, пов'язаними 3 недосконалістю роботи систем реагування на кризи різних рівнів.

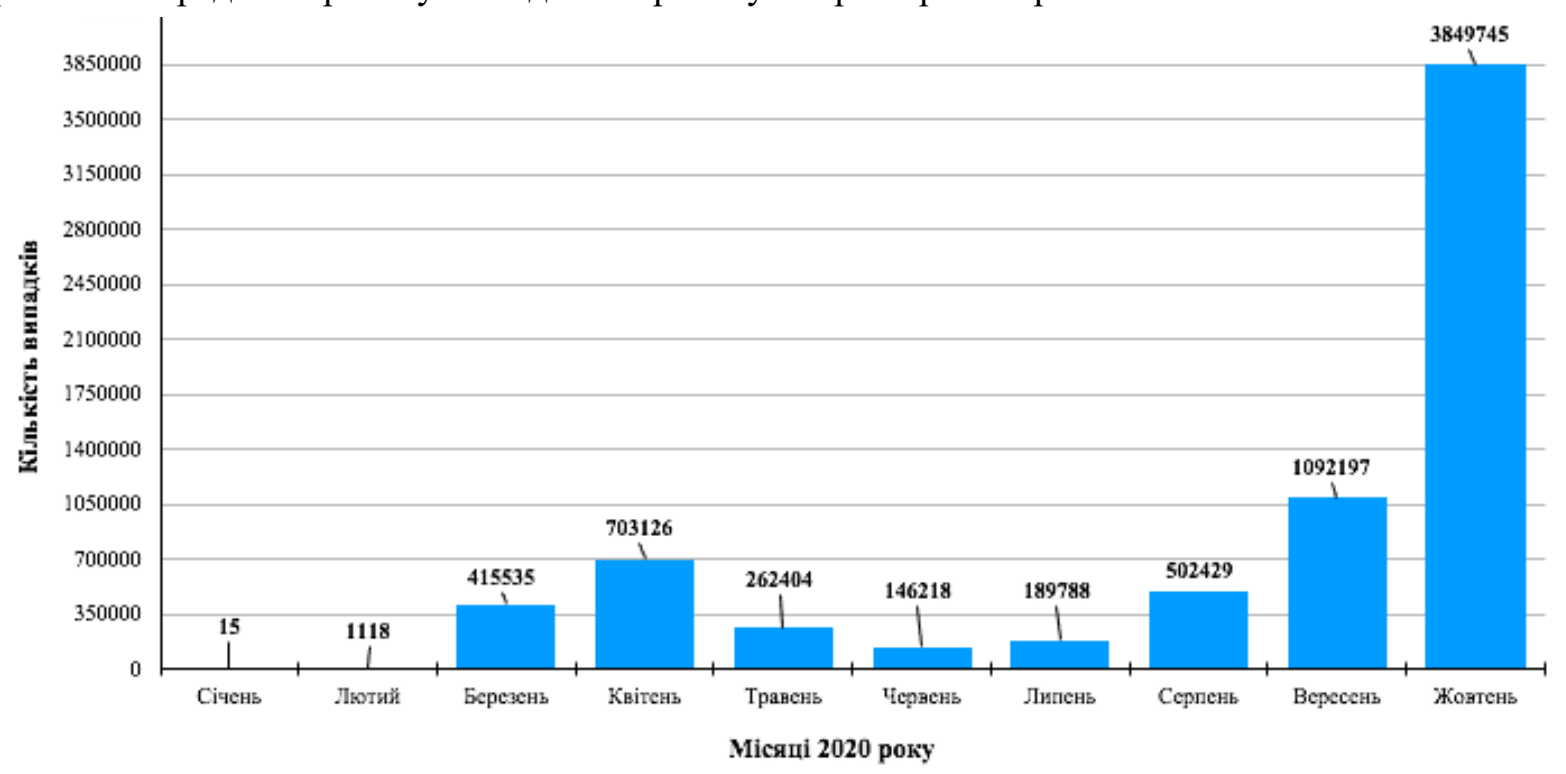

Рис. 1. Динаміка кількості нових випадків захворювання на COVID-19 серед країн ЄC/ЄЕЗ та ВБ$^{1}$ y 2020 p.

Джерело: побудовано авторами на основі даних [6]

${ }^{1}$ Свропейський Союз/Свропейська економічна зона та Велика Британія 
Національні уряди зрозуміли що такими загрозами насамперед стали: порівняно низька потужність територіальних систем охорони здоров'я; недостатня технологічна спроможність медицини боротися зі зростанням рівня захворювання у переважній кількості локацій; нестача лікарів, технічного медичного персоналу, систем захисту лікарів, медичних сестер та усього допоміжного медичного персоналу; нестача у певних регіонах відповідного медичного обладнання; відсутність адекватних планів управління заходами обмеження поширення пандемії; відсутність адекватних протоколів лікування нової хвороби; труднощі закупівель та розподілу обладнання для окремих територій i локацій.

Проте, через деякий час стало також зрозуміло, що як боргові суперечності між країнами $\mathrm{CC}$ в 2008 році, так і карантинні й інші антикризові управлінські рішення органів влади та місцевого самоврядування на рівні країн-членів у 2020 році, крок за кроком досить швидко демонтують єдність і системність спільного внутрішнього ринку ЄС. Під дією антикризових рішень відбувається декомпозиція цільності спільного цивілізаційно-комунікаційного простору $\mathrm{EC}$, спільного європейський духу та загального європейського партнерського менталітету, що $є$ важливою складовою вищезгаданої тріади, основою керованості Європейського Союзу. Компоненти кризи 2020 р. поступово демонтують ті системні економічні фактори, які забезпечували основні докризові економічні успіхи $Є С$ в умовах посилення інтенсивності нормальної конкурентної боротьби зі США, КНР, Японією. 3 іншого боку, проблеми розподілу ресурсів, проблеми оптимізації закупівель медичного й супутнього обладнання, необхідного для подолання кризи, почали викликати конкретну конфронтацію й локальні конфлікти інтересів між окремими країнами $\mathrm{CC}$.

На єдність і здатність приймати несуперечливі для інтересів інших країн-членів оптимальні рішення почали впливати фактичне падіння показників промислового виробництва й надання послуг, ознаки загального економічного спаду та несприятливі прогнози щодо подальшого розгортання загальної економічної кризи. Адаптація до кризових умов на основі певної гармонізації промислових політик мала б відбуватися на основі обгрунтованих прогнозів Європейського банку, Світового банку, МВФ.

МВФ у своєму звіті про перспективи розвитку світової економіки передбачив 3-відсоткове падіння світової економіки у 2020 році. При цьому експерти МВФ зауважили, що цей спад виявиться набагато критичнішим, ніж вплив на світову економіку фінансової кризи 2008-2009 pp. Тільки за умов послаблення пандемії в другій половині 2020 року передбачалося, що зростання світової економіки відновиться у 2021 році і становитиме 5,8 \% [7]. Зважаючи на абсолютно протилежний тренд (станом на жовтень 2020 р.), тобто відсутність сповільнення i, навпаки, значне пришвидшення темпів захворюваності восени 2020 році [8] стає очевидним, що базовий прогнозний сценарій МВФ не стане реальністю: криза буде ще більш жорсткою.

Сьогодні це вимагає швидко, хоча б до кінця 2020 року, наново реалістично переосмислити спрямованість і зміст уже впроваджених управлінських рішень інститутів і структур СС. Тим паче, що деякі країни-лідери $\mathrm{CC}$ демонстрували ще у червні-вересні вагомі успіхи в боротьбі 3 загрозами кризи i почали розраховувати на помірно сприятливий сценарій елімінування кризи, а сьогодні вони знову повторюють майже ті ж рецепти локдаунів. Сьогодні, через 8 місяців, необхідно у новому ключі звернути увагу на спектр вирішених питань i простір невирішених проблем, опираючись на аналіз фактажу «напрацьованого» в просторі відповідальності країн ЄС. Це важливо для структур та інститутів ЄС. Це важливо не менше для структур та інститутів державної політичної й економічної влади України. Адже органи державного управління та влади України будуть неминуче свідомо чи не свідомо орієнтуватися на практику інституцій країн-членів та ЄС в цілому, оскільки ми пов'язані і питаннями сусідства, i питаннями фінансового й торгово-економічного характеру.

Нагадаємо, що на стартовому етапі пандемії в ЄС різнопланові кризові феномени та процеси, що поступово все більше розгорталися на локальних територіях окремих країн-членів, значною мірою усе ж ставали все більш подібними. Система управлінських рішень національних урядів, спрямована на подолання кризи, мала багато спільного, тим більше, що ця системи розвивалися із врахуванням порівнюваного досвіду інших країн $\mathrm{CC}$, які дещо раніше проходили подібні фази медичної, соціальної, економічної компоненти кризи. Слід, також, зауважити, що вже через місяць від перших ознак епідемії на півночі Італії, тобто, в березні 2020, інституції $€$ С також, швидко активізувалися i почали розробляти блоки власних управлінських рішень, орієнтованих на вимір ЄС в цілому. Ці блоки пропозицій і рішень на початку також, як i рішення урядів країн-членів, належали до типу «ad hоc» рішень 3 орієнтацією на пошук 
розв'язання викликів одного безпосередньо актуального етапу реагування на певні складові кризи. Це не були всебічно обгрунтовані рішення, в яких можна було б врахувати далекосяжні результати й наслідки: вони слугували досягненню лише короткотермінових цілей, але були спрямовані на масштаб усього ЄС. Експерти відзначають, що ці низки рішень мали досить високу результативність у короткостроковому періоді, але їх ще не можна вважати складовими певної усвідомленої стратегії компетентних органів та інституцій СС [5].

Для обгрунтування засад стратегічної програми на початку березня органи СС прийняли рішення про фінансування 3 бюджету $\mathrm{CC}$ науково-практичних дослідницьких програм, спрямованих на розробку: 1) медичних препаратів, придатних для перешкоджання поширенню інфекції коронавірусу; 2) нових методів і методик лікування; 3) нових засобів і технологічних рішень для підвищення ефективності діагностування інфекції; 4) нових систем лікування інфекцій коронавірусного типу.

Паралельно з цим, вже у березні 2020 р. вищий орган виконавчої влади СС - Сврокомісія прийняла рішення про початок першої програми 3 обсягом фінансування у 120 млрд євро для закупівлі засобів i підживлення активів для структур країн ЄС, залучених до виробництва засобів спротиву кризі. Одночасно Сврокомісія розпочала щотижневий аналіз ефективності рішень координаційного характеру, що покликані забезпечити ліквідність і стійкість фінансової системи $\mathrm{EC} \mathrm{на} \mathrm{основі} \mathrm{довгострокових} \mathrm{програм}$ рефінансування.

Експерти констатують, що на відміну від повільного розгортання системи рішень ЄС щодо протистояння феноменам фінансової та боргової кризи 2008 року, у 2020 році структурам СС вдалося швидко протягом 2-3-х тижнів розгорнути (як тоді здавалося адекватну) композицію ефективних короткострокових i довгострокових рішень [5, с.5]. Проте, зауважимо, що на даний час фармакологічний сектор країн $Є C$ ще усе не розробив дієвих лікарських засобів протидії збуднику COVID-19, незважаючи на те, що в середині березня на реалізацію цих рішень було запропоновано створити спеціальний інституційний інструмент інвестицій Coronavirus Response Investment Initiative (CRII), у якому було заплановано консолідувати 37 млрд євро 3 метою надання швидкого та еластичного доступу релевантним галузевим структурам країн СС до ліквідних коштів.
На ситуацію 3 розробки змісту рішень та програм ЄС, спрямованих на боротьбу з проявами коронавірусної кризи в різних сферах та галузях, в березні-квітні 2020 р. вплинули кілька факторів: 1) масштаб рівнів бюрократичної процедури ЄС; 2) діалектика суперечності розподілу функцій організації та фінансування охорони здоров'я в країнах-членах та у СС в цілому; 3) завершення семирічного фінансово-бюджетного циклу $\mathrm{EC}$ саме на початку 2020 року. Нагадаємо, що відповідно до угоди про функціонування СС та розподілу обов'язків, політика охорони здоров'я належить до компетенції урядів країн-членів. У політиці охорони здоров' я органи ЄС мають лише допоміжні повноваження. Крім того, передбачено, що надзвичайні ситуації у сфері охорони здоров'я, які зачіпають Європейський Союз загалом, стали спільною компетенцією. Це означає, що як Союз, так і держави-члени можуть створювати i приймати зобов'язуючі акти, але держави-члени можуть робити це лише в тому випадку, якщо Союз відмовляється від своєї компетенції [9].

Через деякий час була створена i диверсифікована програма $\mathrm{CC}$ щодо врегулювання криз, яка охоплює охорону здоров'я, економіку, подорожі й транспорт, дослідження, освіту, цивільний захист і боротьбу 3 дезінформацією [10]. Свропейська комісія в березні-травні розробила управлінські рішення щодо: 1) координації в колишніх сферах управління охороною здоров'я та економічної кризи, спричинені епідемією коронавірусу; 2) суперечливих або конфліктних ситуацій, викликаних рішеннями окремих держав-членів.

Вирішення проблем координації є складним завданням, оскільки інструменти Комісії (за допомогою керівних принципів, регламентів i технічних етапів) повинні використовуватися для збалансування рішень на основі національних уподобань, які, по суті, $є$ компетенцією національної держави. Крім того, інституції ЄС повинні відігравати ключову роль у згладжуванні конфлікту інтересів і забезпеченні солідарності між державами-членами. Перший має на меті якомога ефективніше подолати кризу у сфері охорони здоров'я та забезпечити належне функціонування внутрішнього ринку, що може прискорити відновлення економіки. Хоча останнє завдання полягає у визначенні пріоритетів у відповідях Співтовариства, включаючи будь-яку наднаціональну фінансову установу або механізм, який може надати додаткові ресурси на додаток до сум, програм та підтримуючої монетарної політики, оприлюдненої Свропейською комісією. 
Компаративістський аналіз, на жаль, засвідчує і те, що період стабілізації, який розпочався в червні 2020 p. i давав надії на поступове оздоровлення економіки провідних країн $\mathrm{CC}$, таких як Німеччина, Франція, Нідерланди, несподівано різко завершився в жовтні 2020 року. Зараз, у кінці жовтня 2020 розпочався якісно новий етап ескалації обсягів загроз, створюваних пандемією (див. рис.1). Паралельно все більше погіршуються показники продуктивності економічних систем більшості країн $\mathrm{CC}$, супроводжуючись погіршенням профілів «раціональних очікувань» економічних агентів мікро- та нанорівня. Це має об'єктивні епідеміологічні причини: станом на 31.10.2020 р. у Франції було зафіксовано 49,2 тисячі нових випадків захворювання на добу, в Італії - 31,1 тис., у Великій Британії - 24,4 тис., Польщі - 21,6 тис. та Німеччині - 19,1 тис. нових випадків заражень COVID-19. Загалом, дані поширення вірусу складають загрозливу картину як для $\mathrm{CC}$ загалом, так і для національних урядів країн зокрема (див. рис. 1, рис. 2). У відповідь на це Велика Британія, Франція, Німеччина, Чехія та деякі інші країни СС вводять розпорядження про жорсткий карантин орієнтовною тривалістю 2 місяці.

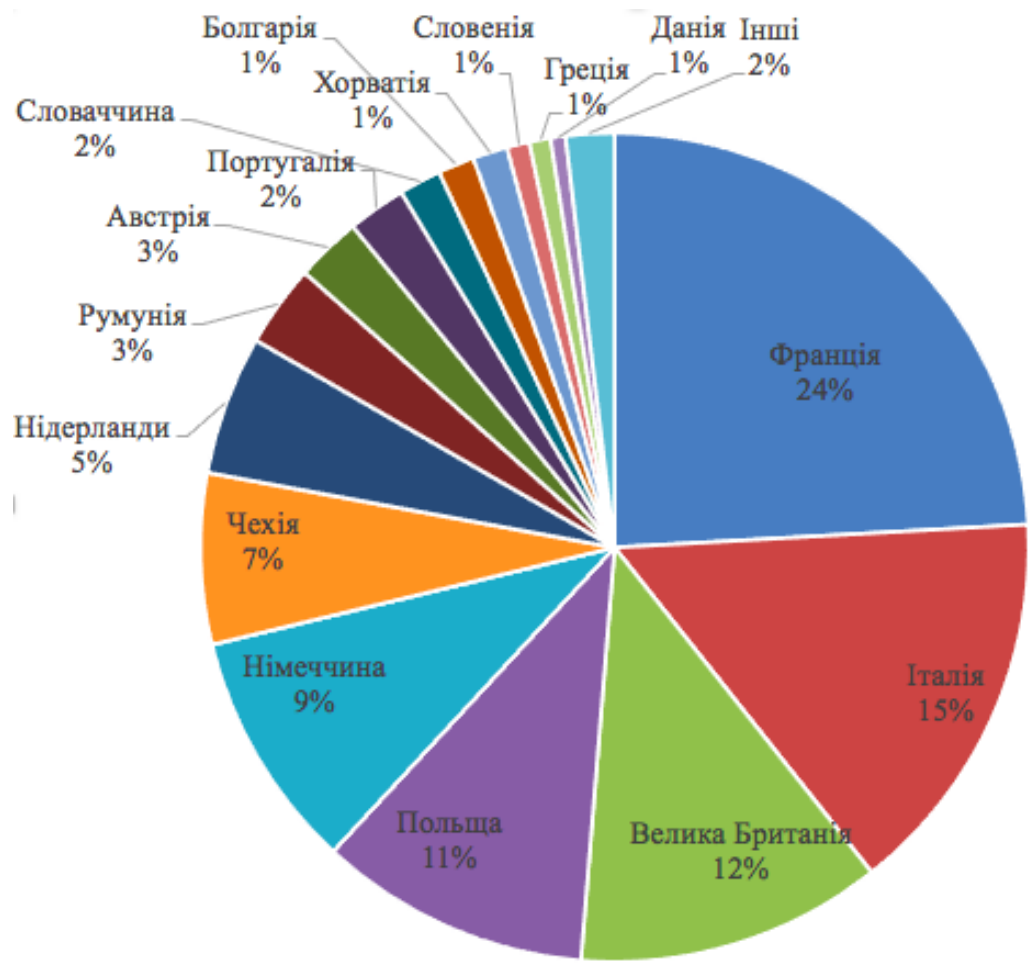

\section{Рис. 2. Розподіл нових випадків захворювання на COVID-19 серед країн СC/СЕЗ та ВБ станом на 31 жовтня 2020 p.}

Джерело: побудовано авторами на основі даних [6]

Сценарний аналіз управлінського аспекту «регулювання» обставин пандемії 3 позиції сьогодення, однозначно свідчить і про те, що весь попередній період можна вважати лише стартовим етапом. До кінця вересня ще можна було припускати, що управлінські рішення структур та інституцій ЄС були досить ефективними. Станом на 31 жовтня 2020 р. необхідно визнати, що у цілому система управлінських рішень структур та інститутів виявилася недостатньо ефективною в довгостроковому періоді. Це очікувано призведе до значного економічного ослаблення передових промислово-фінансових груп провідних країн $\mathrm{CC}$ $\mathrm{i}$, одночасно, до ослаблення фінансової спроможності $\mathrm{CC}$ в цілому. В такому випадку розраховувати Україні на суттєву фінансову допомогу Європейського банку та інших інститутів ЄС недоцільно.

У цьому зв'язку вбачається за нагальне провідним експертним центрам України спільно iз раціональними проукраїнськими державними діячами та політиками розробити альтернативи комплексних стратегій для обмеження поширення пандемії, сформувати активний Антикризовий державний фонд шляхом законодавчого соціально-справедливого 
регламентування балансу доходів i витрат антагоністичних за рівнем багатства соціальних прошарків. У цьому зв'язку видається доцільним логічно та юридично обгрунтувати необхідність негайного введення 32021 року в українській державі прогресивного оподаткування «внутрішніх» доходів власників великих капіталів i трансфертних потоків виведення капіталів в офшорні юрисдикції. Ввести відповідні зміни до проекту державного бюджету на 2021 рік. За рахунок перегрупованих таких чином коштів українського суспільства варто розробити та прийняти максимально обгрунтовані цільові програми фінансування сфер, що перебувають на першій (медицина), другій (малий і середній бізнес) та подальших лініях оборони у війні проти пандемії. Одним із ефективних інструментів управління процесом комплексної боротьби 3 факторами-каналами розгортання кризи міг би стати антикризовий форум «Ресурси бізнесу, громадськості та політики проти пандемії».

Висновки i перспективи подалыших досліджень. Протягом завершальних тижнів жовтня 2020 р. перебіг кризи пандемії в країнахчленах $\mathrm{CC}$ та в Союзі загалом виявився набагато складнішим, ніж на початковому етапі карантинних обмежувальних заходів у квітнітравні 2020 р. Аналізувати причини майже квадратичного темпу зростання нових випадків зараження COVID-19 необхідно починаючи 3 вересня, оскільки загострення ситуації з кількістю захворювання на добу вказують на досить низьку стратегічну ефективність управлінських рішень інститутів i структур ЄC першого етапу, насамперед, рішень санітарно-епідемічного характеру.

На другому, більш загрозливому етапі еволюції кризового комплексу COVID-19, що, як свідчить зміна тренду захворюваності, розпочався у жовтні 2020 р. (див. рис. 1), обмежувальні карантинні заходи у форматі надзвичайного стану певної адміністративної одиниці або навіть цілої країни знову стають основним управлінським рішенням. Але це певною мірою непродумане повторення умовно успішного досвіду попереднього березневого етапу. Адже залишаються не прорахованими ризики того, чи локдауни обернуться знову суто тимчасовим рішенням для сповільнення темпів поширення пандемії, як це вже відбулося у березні-червні 2020 р. Не прораховані ризики того, наскільки локдауни послаблять поточний економічний ресурс країн, необхідний для подальшої боротьби 3 пандемією. Не оприлюднюються стратегічні рішення щодо того, яким чином інститути та структури ЄС зможуть приборкати суперечності й перекоси в тенденціях формування конкурентоспроможності національних компаній і національних економік країн-членів.

Негативні тренди дещо сповільнюють запровадження національними урядами системи штрафів за нехтування вимогами щодо обов'язкового використання в публічних місцях масок та інших індивідуальних засобів захисту, що протидіють аерозольному та предметноконтактним каналам поширення збудника. Проте, каральні заходи $є$ обмежувальними стосовно особистої свободи, а тому швидко викликають психологічну втому соціальних акторів.

У цьому зв'язку увагу як політиків, так i громадських діячів ЄС та України доцільно сфокусувати на багаторівневому питанні: що саме необхідно «удосконалити та виробити» в колективному «європейському менталітеті», щоб приборкати сьогодні ще майже повністю неконтрольоване поширення збудника від громади до громади, від країни до країни? За яких умов карантинні заходи здатні сповільнити темпи зростання захворюваності? Як ці карантинні умови вплинуть на національні економіки та спільний економічний простір? Які компенсаційні механізми підтримання рівня економічної активності зможуть запропонувати інститути та структури ЄС? Які можливості або виклики вони створять, зокрема, для української економіки? Наскільки глибоко європейські аналітики, економісти та політики аналізували тренди падіння ВВП у другому кварталі 2020 року через COVID-19, яке склало в Японії на 7,9 \%, у Республіці Корея - 3,2\%; в той час, коли економіка Єврозони скоротилася на $11,8 \%$, країн СC - на 11,4\% (за фінальним звітом - найбільше за усі 25 років ведення статистики), Китай демонстрував економічний ріст $11,5 \%$ ? До того ж, після відновлення через послаблення заходів карантину показники виявилися нижчими, ніж у третьому кварталі 2019 року, для Єврозони - на $4,3 \%, \mathrm{CC}$ - на 3,9\% [11].

Отримати адекватні відповіді на ці питання можливо тільки на основі розробки комплексних кількісних моделей реагування вогнищ та каналів поширення пандемії на управлінські, організаційні, правові та економічні рішення. На нашу думку, саме ці питання повинні визначати перспективи і вектор подальших досліджень. 


\section{ПЕРЕЛІК ВИКОРИСТАНИХ ДЖЕРЕЛ}

1. Hall P. Varieties of Capitalism: The Institutional Foundations of Comparative Advantage / Hall P., Soskice D. Oxford: Oxford University Press; 2001. - 540 p.

2. Черленяк I.I. Виклики антикризового управління економікою в умовах пандемії / Черленяк, I.I., Курей О.А. // Науковий вісник Ужгородського університету. Серія «Економіка». - 2020. - Вип. 1(55). - С.10-18

3. Boin A. The Transboundary Crisis: Why we are unprepared and the road ahead / A.Boin // Journal of Contingencies and Crisis Management. - 2019. - Vol.27. - P.94-99

4. Ekengren M. European Union Crisis Management: Challenges for Research and Practice [Електронний ресурс] / Ekengren M., Groenleer M. // International Journal of Emergency Management. - 2006, Jan. Режим доступу: https://www.researchgate.net/profile/Martijn_Groenleer/publication/264441608_European_Union_crisis_management_ Challenges_for_research_and_practice/links/55c885d308aebc967df8c758/European-Union-crisis-management-

Challenges-for-research-and-practice.pdf

5. Szijártó N. Az Európai Unió gazdasága és a koronavírus (COVID-19) Az Európai Bizottság útkeresése / Szijártó N. // Kihívások. - 2020. - 236. Режим доступу: http://real.mtak.hu/108265/1/Szijarto_Kihivasok_200417.pdf

6. European Union Law: Text and Materials [Електронний ресурс] / Damian Chalmers, Gareth Davies, Georgio Monti. - Cambridge: Cambridge University Press, 2010. Режим доступу: https://qap.ecdc.europa.eu/public/extensions/ COVID-19/COVID-19.html\#global-overview-tab

7. World Economic Outlook (The Great Lockdown). Washington, DC: International Monetary Fund, 2020. - 158 p.

8. Всесвітня організація охорони здоров'я: офіційна сторінка [Електронний ресурс]. - Режим доступу: https://covid19.who.int

9. Consolidated versions of the Treaty on European Union and the Treaty on the Functioning of the European Union [Електронний ресурс] // Official Journal of the European Union. - 2008. - Vol. 51. Режим доступу: https://eurlex.europa.eu/legal-content/EN/TXT/HTML/?uri=OJ:C:2008:115:FULL\&from =EN

10. European Commission. Overview of the Commission's Response [Електронний ресурс]. - Режим доступу: https://ec.europa.eu/info/live-work-travel-eu/health/coronavirus-response/overview-commissions-response_en

11. ВВП країн $Є С$ рекордно зріс після «коронавірусного» падіння [Електронний ресурс] // Економічна правда. 2020, 30 жовтня. Режим доступу: https://www.epravda.com.ua/news/2020/10/30/666782/

\section{REFERENCES}

1. Hall, P., \& Soskice, D. (2001) Varieties of Capitalism: The Institutional Foundations of Comparative Advantage. Oxford: Oxford University Press [in English]

2. Cherleniak, I.I. \& Kurei, O.A. (2020) Vyklyky antykryzovoho upravlinnia ekonomikoiu v umovakh pandemii [Crisis Management Challenges in a Pandemic]. Naukovyi visnyk Uzhhorodskoho universytetu. Seriia «Ekonomika». Scientific Bulletin of Uzhhorod University. Series «Economics», 1(55), 10-18 [in Ukrainian]

3. Boin, A. (2019) The Transboundary Crisis: Why we are unprepared and the road ahead. Journal of Contingencies and Crisis Management, 27, 94-99 [in English]

4. Ekengren, M., \& Groenleer, M. (2006) European Union Crisis Management: Challenges for Research and Practice. International Journal of Emergency Management. Retrieved from: https://www.researchgate.net/profile/ Martijn_Groenleer/publication/264441608_European_Union_crisis_management_Challenges_for_research_and_practi ce/links/55c885d308aebc967df8c758/European-Union-crisis-management-Challenges-for-research-and-practice.pdf [in English]

5. Szijártó, N. (2020) Az Európai Unió gazdasága és a koronavírus (COVID-19) Az Európai Bizottság útkeresése [The European Union's economy and the coronavirus (COVID-19). The European Commission's roadmap]. Kihívások Challenges, 236. Retrieved from: http://real.mtak.hu/108265/1/Szijarto_Kihivasok_200417.pdf [in Hungarian]

6. Chalmers, D., Davies, G. \& Monti G. (2010) European Union Law: Text and Materials. Cambridge: Cambridge University Press. Retrieved from: https://qap.ecdc.europa.eu/public/extensions/COVID-19/COVID-19.html\#globaloverview-tab [in English]

7. World Economic Outlook (The Great Lockdown) (2020). Washington, DC: International Monetary Fund [in English]

8. World Health Organization. Retrieved from: https://covid19.who.int [in English]

9. Consolidated versions of the Treaty on European Union and the Treaty on the Functioning of the European Union (2008). Official Journal of the European Union, 51. Retrieved from: https://eur-lex.europa.eu/legal-content/EN/TXT/ HTML/?uri=OJ:C:2008:115:FULL\&from =EN [in English]

10. European Commission. Overview of the Commission's Response. Retrieved from: https://ec.europa.eu/info/livework-travel-eu/health/coronavirus-response/ overview-commissions-response_en [in English]

VVP krain YeS rekordno zris pislia «koronavirusnoho» padinnia (2020) [EU GDP grew at a record high after the "coronavirus" decline] Ekonomichna pravda. - Economic truth. Retrieved from: https://www.epravda.com.ua/news/2020/ 10/30/666782/ [in Ukrainian] 